\title{
PENGARUH KONSEP DIRI TERHADAP PRESTASI BELAJAR MATEMATIKA SISWA SMAN 102 JAKARTA
}

\author{
Nur Alamsyah \\ Program Studi Teknik Informatika, Universitas Indraprasta PGRI \\ Email: alamcbr11@gmail.com
}

\begin{abstract}
Abstrak
Tujuan utama dari penelitian ini adalah untuk mengetahui pengaruh konsep diri siswa terhadap prestasi belajar matematika siswa. Populasi dari penelitian ini adalah seluruh siswa kelas XI Sekolah Menengah Atas Negeri 102 Jakarta Timur. Sampel diambil dengan teknik sampel random sampling sebanyak 30 siswa. Data prestasi belajar matematika menggunakan tes formatif dan data konsep diri diperoleh menggunakan angket skala Likert. Metode penelitian menggunakan teknik korelasi regresi sederhana. Hasil uji hipotesis penelitian ditemukan nilai $F_{\text {hitung }}>F_{\text {tabel }}(21,64>4,20)$. Terdapat pengaruh signifikan konsep diri terhadap prestasi belajar matematika siswa. Konsep diri yang dimiliki siswa baik maka prestasi belajar matematika akan baik.
\end{abstract}

Kata Kunci: Konsep Diri, Prestasi Belajar, Matematika

\section{Pendahuluan}

Bidang studi matematika termasuk bidang studi wajib yang telah diperkenalkan kepada peserta didik sejak dari pendidikan dasar. Bahkan beberapa orang tua telah pula membiasakan anak untuk akrab dengan matematika. Beberapa sekolah taman kanak-kanak telah pula mengajarkan konsep bilangan sebagai salah satu langkah awal bagi siswa untuk lebih mengenal matematika, kebanyakan siswa mendengar pelajaran matematika sudah gelisah, merasa tidak percaya diri karena matematika adalah mata pelajaran yang sering kali menguras otak sehingga siswa mengganggap pelajaran matematika itu adalah pelajaran yang sangat sulit.

Pada pendidikan di tingkat menengah atas, siswa sudah dihadapkan mata pelajaran yang konkret, belajar matematika tanpa memahami konsep dan latihan yang kontinu tidak mungkin mudah dikuasai. Dalam kegiatan belajar dibatasi beberapa hal antara lain adalah kurangnya konsep diri yang dimiliki oleh siswa seperti keprcayaan diri dan harga diri sehingga prestasi belajar siswa tersebut belum memenuhi harapan, kurangnya konsep diri tersebut maka sebagian besar siswa kurang menguasai materi yang diberi oleh guru.

Faktor apa sebenarnya yang mempengaruhi persepsi siswa terhadap bidang studi matematika, dan faktor apa yang telah memperburuk kualitas prestasi belajar matematika siswa? Untuk dapat menjawab pertanyaan tersebut dibutuhkan penelitian yang lebih mendalam, namun dari beberapa analisis sementara yang dilakukan, terdapat banyak faktor yang mempengaruhi prestasi belajar matematika siswa di antaranya kurangnya rasa percaya diri siswa pada akhirnya meruntuhkan keyakinan dan mengubah konsep diri. Dalam diri siswa terbentuk sebuah kesimpulan bahwa bidang studi matematika bukanlah bidang studi yang menyenangkan untuk dipelajari sehingga tertanam keyakinan bahwa bidang studi matematika adalah bidang studi yang menjemukan dan perlu dihindari.

Rangkaian proses yang berkelanjutan sering membuat siswa merasa lelah dan pada akhirnya hilang kesabaran serta berakibat pada keengganan belajar. Kondisi sebaliknya berlaku untuk siswa yang menyukai tantangan belajar. Matematika merupakan sebuah proses belajar yang sangat menarik dan penuh keunikan. Karaktersitik demikian membuat sebagai siswa merasa larut dan sangat menyenangi bidang studi matematika. 
Faktor yang mempengaruhi menurunnya prestasi belajar matematika berasal dari internal siswa, yaitu faktor fisiologis atau kondisi fisik individu dan faktor psikologis. Di antara kedua faktor tersebut, yaitu faktor fisiologis dan psikologis, diduga bahwa faktor fisiologis kurang begitu besar pengaruhnya terhadap pencapaian prestasi belajar siswa, dibandingkan dengan faktor psikologis. Dengan berpedoman pada fenomena tersebut, dapat diduga adanya pengaruh dari konsep diri siswa terhadap prestasi belajar matematika.

\section{Tinjauan Pustaka}

\section{Prestasi Belajar Matematika}

Menurut Gagne (dalam Djiwandoro, 2007), prestasi belajar dapat dibedakan dalam lima kategori yang di antaranya adalah: 1) informasi verbal, 2) kemahiran intelektual, 3) pengaturan kegiatan kognitif, 4) sikap, dan 5) keterampilan motorik. Menurut Hakim (2007) seseorang yang ingin meningkatkan prestasi belajarnya ia harus mampu menemukan faktor penghambat belajar dan mengatasi hambatan belajar secara bijak. Langkah awal untuk meningkatkan prestasi belajar harus berlangsung dari dalam diri peserta didik. Jika kondisi yang ada dalam diri siswa mampu mendorong untuk memperbaiki prestasi yang telah dicapai maka akan terbentuk sebuah motivasi memenuhi keinginan tersebut. Adapun faktor lingkungan berperan sebagai faktor pemicu lahirnya kesadaran untuk mencapai prestasi belajar optimal.

Menurut Bloom (dalam Arikunto, 2006), hasil belajar dibedakan menjadi tiga aspek yaitu kognitif, afektif dan psikomotorik. Prestasi merupakan kecakapan atau hasil konkret yang dapat dicapai pada saat atau periode tertentu. "hasil belajar dibedakan menjadi tiga aspek yaitu kognitif, afektif dan psikomotorik". Menurut Winkel (2000) bahwa "prestasi belajar merupakan bukti keberhasilan yang telah dicapai oleh seseorang". Prestasi belajar merupakan hasil maksimum yang dicapai oleh seseorang setelah melaksanakan usaha-usaha belajar. Prestasi belajar di bidang pendidikan adalah hasil dari pengukuran terhadap peserta didik yang meliputi faktor kognitif, afektif dan psikomotor setelah mengikuti proses pembelajaran yang diukur dengan menggunakan instrumen tes atau instrumen yang relevan.

Dapat disimpulkan bahwa prestasi belajar adalah hasil pengukuran dari penilaian usaha belajar yang dinyatakan dalam bentuk simbol, huruf maupun kalimat yang menceritakan hasil yang sudah dicapai oleh setiap anak pada periode tertentu. Prestasi belajar merupakan hasil dari pengukuran terhadap peserta didik yang meliputi faktor kognitif, afektif dan psikomotor setelah mengikuti proses pembelajaran yang diukur dengan menggunakan instrumen tes yang relevan.

Prestasi belajar matematika merupakan hasil dari pengukuran terhadap peserta didik yang meliputi faktor kognitif, afektif dan psikomotorik setelah mengikuti proses pembelajaran matematika pada periode tertentu yang diukur dengan menggunakan instrumen tes yang relevan. Prestasi belajar matematika dapat diketahui setelah diadakan evaluasi yang dapat memperlihatkan tinggi rendahnya prestasi belajar siswa dalam pelajaran matematika pada suatu periode. Seperti apa yang dijelaskan BSNP (2005) sebagai berikut: "ketuntasan belajar setiap indikator yang telah ditetapkan dalam suatu kompetensi dasar berkisar antara 0 $100 \%$. Kriteria ideal ketuntasan untuk masing-masing indikator $75 \%$. Satuan pendidikan harus menentukan kriteria ketuntasan minimal dengan mempertimbangkan tingkat kemampuan rata-rata peserta didik serta kemampuan sumber daya pendukung dalam penyelenggaraan pembelajaran. Satuan pendidikan diharapkan meningkatkan kriteria ketuntasan belajar secara terus menerus untuk mencapai kriteria ketuntasan ideal".

Prestasi belajar matematika untuk tingkat SMA meliputi faktor kognitif, afektif dan psikomotorik terhadap penguasaan materi Logika, Aljabar, Geometri, Trignometri, Kalkulus, serta Statistika dan Peluang, yang masing-masing didistribsikan sesuai tingkatan kelasnya. 
Seorang siswa yang telah melakukan kegiatan belajar matematika, dapat diukur prestasinya setelah melakukan kegiatan belajar tersebut dengan menggunakan suatu alat evaluasi. Jadi, prestasi belajar matematika adalah hasil belajar yang dicapai oleh siswa setelah mempelajari matematika dalam kurun waktu tertentu dan diukur dengan menggunakan alat evaluasi (tes).

Berdasarkan pengertian di atas, maka dapat dijelaskan bahwa prestasi belajar adalah tingkat kemampuan yang dimiliki siswa dalam menerima, menolak dan menilai informasi-informasi yang diperoleh dalam proses belajar mengajar. Prestasi belajar seseorang sesuai dengan tingkat keberhasilan sesuatu dalam mempelajari materi pelajaran yang dinyatakan dalam bentuk nilai atau rapor setiap bidang studi setelah mengalami proses belajar mengajar. Prestasi belajar siswa dapat diketahui setelah diadakan evaluasi. Hasil dari evaluasi dapat memperlihatkan tentang tinggi atau rendahnya prestasi belajar siswa.

\section{Pengertian Matematika}

Dalam pandangan formalitas matematika adalah penelaahan struktur abstrak yang didefinisikan secara aksioma dengan menggunakan logika simbolik dan notasi. Matematika merupakan dasar yang mendasari ilmu pengetahuan yang lain. Dalam kamus besar bahasa Indonesia (2003) bahwa "matematika adalah ilmu tentang bilangan, hubungan antara bilangan dan prosedur operasional yang digunakan dalam penyelesaian masalah mengenai bilangan".

Menurut Suriasumantri (2009) bahwa " matematika adalah bahasa yang melambangkan serangkaian makna dari pernyataan yang ingin kita disampaikan. Lambang-lambang matematika bersifat artificial yang baru mempunyai arti setelah sebuah sebuah makna diberikan padanya". Menurut Wittgenstein (dalam Suriasumantri, 2009) bahwa "matematika adalah metode berpikir logis", artinya matematika merupakan suatu cara atau teknik yang digunakan dalam berpikir logis. Sehingga kebenaran dalam matematika merupakan kebenaran yang berdasarkan logika bukan empiris atau kenyataan. Hal ini karena objek dalam matematika merupakan benda abstrak atau khayal seperti angka-angka dan simbolsimbol.

Menurut Russefendi (1991) mengemukakan bahwa matematika merupakan suatu ilmu yang berhubungan dengan penelaahan bentuk-bentuk atau struktur-struktur abstrak yang berhubungan di antara hal itu. Untuk dapat memahami struktur-struktur serta hubunganhubungannya yang diperlukan pemahaman tentang konsep-konsep yang terdapat dalam matematika itu. Ini mengisyaratkan bahwa belajar matematika adalah belajar tentang konsepkonsep dan struktur-struktur serta mencari hubungan antara konsep-konsep dan strukturstruktur tersebut.

Rusefendi (1991) menyebutkan bahwa belajar matematika adalah belajar tentang konsepkonsep dan struktur-struktur yang terdapat dalam bahasan yang dipelajari serta mencari hubungan-hubungan antara konsep-konsep dan struktur-struktur tersebut, disebutkan pula, matematika mengelompokkan perwujudan alamiah menjadi pola-pola atau bentuk-bentuk tertentu. Selain menghubungkan matematika melakukan penelaahan pola atau bentuk di dalam matematika berarti mewujudkan struktur-struktur. Adapun hubungan-hubungan pola di dalam matematika dapat membentuk rumus, teorema atau dalil matematika.

Matematika adalah ilmu pengetahuan yang termasuk ke dalam atau mungkin yang paling padat dan tidak mendua arti. Lebih lanjut disebutkan bahwa tujuan pengajaran matematika (modern) adalah untuk meluruskan dan mempermudah siswa belajar berhitung dan cabangcabang lainnya, bukan untuk mempersulit. Setelah menelaah berbagai pendapat tersebut di atas, maka matematika adalah mata pelajaran yang memuat ide-ide, konsep-konsep abstrak yang tersusun secara hierarkis dan terpola menjadi rumus, teorema atau dalil yang dapat 
dipergunakan secara paten untuk pemecahan masalah dalam mata pelajaran matematika itu sendiri maupun untuk aplikasi dalam ilmu pengetahuan dan teknologi.

Matematika menggunakan abstraksi dan penalaran logika yang dikembangkan dari pencacahan, perhitungan, pengukuran, dan pengkajian sistematika terhadap bentuk dan gerak objek fisika. Kini matematika dipakai di seluruh dunia sebagai alat penting di berbagai bidang, termasuk ilmu pengetahuan alam, rekayasa, medis, dan ilmu pengetahuan sosial seperti ekonomi dan psikologi. Tingkat kesulitan suatu jenis matematika disebabkan oleh sulit dan kompleksnya gejala yang penyelesaiannya diusahakan dicari atau didekati oleh perumusan (model matematikanya) dengan menggunakan jenis atau cabang matematika tersebut.

Dapat disimpulkan bahwa matematika adalah suatu pengetahuan yang dipelajari sebagai hasil dari pemikiran manusia dalam penyelesaian masalah yang menggunakan bahasa simbol khususnya bilangan dalam penyampaiannya terhadap orang lain. Pengetahuan matematika tersusun konsisten berdasarkan logika berpikir.

\section{Pengertian Konsep Diri}

Konsep berfungsi sebagai fondasi dalam mencapai keberhasilan dalam kehidupan, konsep diri juga berperan sebagai penentu arah dalam bertindak. Siswa dengan konsep diri yang positif cenderung bertindak lebih positif dalam belajar, tugas yang diberikan guru akan diselesaikan dengan penuh tanggung jawab dan hambatan belajar ia jadikan sebagai tantangan dan mampu semangat belajarnya. Beberapa faktor yang mempengaruhi konsep diri di antaranya adalah: 1) cita-cita, 2) citra diri, dan 3) harga diri. (Gunawan dan Setiyono, 2007)

Menurut Brooks dan Emmerst (dalam Jalaluddin, 2005), ada lima tanda orang yang memiliki konsep diri tinggi atau positif yaitu: 1) ia yakin akan kemampuannya mengatasi masalah, 2) ia merasa setara dengan orang lain, 3) ia menerima pujian tanpa rasa malu, 4) ia menyadari bahwa setiap orang mempunyai berbagai perasaan, keinginan dan perilaku yang tidak seluruhnya disetujui masyarakat, dan 5) ia mampu memperbaiki dirinya karena ia sanggup mengungkapkan aspek-aspek kepribadian yang tidak disenanginya dan berusaha mengubahnya.

Tanda-tanda orang yang memiliki konsep diri rendah atau negatif, di antaranya yaitu:

1. Ia peka pada kritik, orang ini sangat tidak tahan kritik yang diterimanya, dan mudah marah atau naik pitam. Bagi orang ini koreksi sering kali dipersepsi sebagai usaha untuk menjatuhkan harga dirinya.

2. Orang yang memiliki konsep diri rendah atau negatif cenderung menghindari dialog yang terbuka dan bersih keras mempertahankan pendapatnya dengan berbagai justifikasi atau logika yang keliru.

3. Bersikap hiperkritis terhadap orang lain, selalu mengeluh, mencelah atau meremehkan apapun dan siapapun. Mereka tidak pandai dan tidak sanggup mengungkapkan penghargaan atau pengakuan pada kelebihan orang lain.

4. Orang yang konsep dirinya rendah atau negatif, cenderung merasa tidak disenangi orang lain, ia merasa tidak diperhatikan.

5. Orang yang konsep dirinya rendah atau negatif, bersikap pesimis terhadap kompetisi seperti terungkap dalam keengganannya untuk bersaing dengan orang lain dalam membuat prestasi.

Menurut Ainon dan Abdullah (2006), menjelaskan bahwa konsep diri adalah gabungan segala kepercayaan diri juga meliputi persepsi lingkungan. Masing-masing individu akan mereaksi atas ucapan dan cara pandang orang lain pada dirinya. Pada orang-orang tertentu 
yang bersifat sensitif, cara pandang dan pernyataan lingkungan akan berpengaruh pada konsep diri, dijelaskan juga bahwa konsep diri adalah semua ide, pikiran, kepercayaan dan pendirian yang diketahui individu tentang dirinya. Pernyataan ini secara nyata menggambarkan bahwa keberadaan lingkungan memiliki peran penting dalam pengembangan konsep diri.

Cita-cita yang dibangun siswa merupakan tujuan hidup yang ingin dicapai, untuk dapat meraih cita-cita siswa harus mampu menempatkan diri sesuai dengan karakteristik dari citacita yang diharapkan. Siswa dengan cita-cita menjadi dokter akan menyesuaikan konsep dirinya sesuai dengan profesi seorang dokter. Konsep diri merupakan kemampuan melihat diri sendiri dengan segala kekurangan dan kelebihannya. Untuk mampu mengukur seberapa jauh kesanggupan dan kemampuan meraih cita-cita, setiap individu harus mampu melihat dan mengukur potensinya.

Kondisi yang ada dan dimiliki akan memberi arah bagi sesesorang untuk mempersepsi diri dan selanjutnya membangun konsep diri sesuai dengan pemahaman atas potensi yang dimiliki. Siswa sebagai peserta didik diharapkan membangun konsep diri ideal dan menghindarkan diri dari perilaku yang dapat memupus harga diri. Anggapan diri sebagai siswa yang pintar akan membuka peluang untuk tertib dan bertanggung jawab dalam belajar. Siswa yang menyatakan dirinya sebagai siswa yang malas dan bodoh, maka pada akhirnya ia akan menempatkan dirinya sesuai dengan persepsi yang ia bangun sesuai dengan persepsi yang mendasarinya.

Konsep diri (self concept) merupakan hal yang sering dibahas serta dianggap besar pengaruhnya terhadap tingkah laku seseorang. Hal tersebut dikarenakan konsep diri adalah persepsi atau penilaian seseorang terhadap dirinya. Penilaian tersebut merupakan keyakinan seseorang mengenai dirinya yang meliputi gambaran mengenai fisiknya, psikis, sosial dan prestasinya. Selain itu, konsep diri juga terbentuk berdasarkan pemikiran, perasaan dan pengalaman emosional, individu mengenai dirinya sendiri.

Konsep diri yang dipunyai seseorang akan turut menentukan bagaimana ia menerima, merasakan dan merespon lingkungannya. Seseorang yang berpikir bahwa dirinya kurang baik maka ia menganggap remeh dirinya serta selalu membayangkan kegagalan di setiap usaha yang akan dilakukan, selanjutnya ia akan enggan untuk mencoba mengatasi kesulitan yang dihadapi. Tingkah laku tersebut menunjukkan keyakinannya bahwa orang tersebut tidak mempunyai kemampuan untuk melakukan suatu usaha dengan sebaik mungkin. Keyakinan tersebut mencerminkan sikap dan pandangan negatif terhadap dirinya sendiri.

Pandangan negatif terhadap dirinya menyebabkan individu mengharapkan tingkat keberhasilan yang akan dicapai hanya pada taraf yang rendah. Patokan rendah tersebut menyebabkan orang yang bersangkutan tidak mempunyai motivasi untuk mencapai prestasi yang gemilang. Sebaliknya, seseorang yang menganggap dirinya positif perbuatan akan dilakukan sungguh-sungguh, ia akan mau mencoba mengatasi kesulitan yang dihadapi, sehingga akan bertambah kemungkinannya untuk sukses. Jadi, seseorang yang mempunyai konsep diri yang tinggi akan menunjukkan tingkah laku yang berbeda dengan orang yang mempunyai konsep diri yang rendah. Orang yang mempunyai konsep diri yang tinggi akan menunjukkan tingkat aspirasi yang tinggi, optimis, percaya diri, realistis, mandiri, dan dapat menyesuaikan diri dengan baik.

Perbedaan keseimbangan antara pengalaman hidup dan kebutuhan untuk mencapai prestasi antara individu yang satu dengan individu yang lain, maka akan menyebabkan perbedaan tafsiran tentang dirinya sendiri. Seseorang yang mempunyai tafsiran negatif terhadap pengalaman hidup yang dialaminya, maka akan menyebabkan pandangan dan sikap negatif 
terhadap diri sendiri. Sebaliknya, seseorang yang mempunyai tafsiran positif terhadap pengalaman hidup yang dialaminya, maka akan menyebabkan pandangan hidup dan sikap positif terhadap dirinya sendiri.

Sikap dan pandangan negatif terhadap diri sendiri menyebabkan individu memandang seluruh hidupnya dengan penuh rasa pesimis, penuh ketidakmampuan dan kurang percaya diri. Sikap dan pandangan yang positif terhadap diri sendiri menyebabkan individu memandang seluruh hidupnya dengan penuh rasa percaya diri dan selalu merasa optimis.

Selanjutnya, dalam penelitian ini konsep diri yang akan diteliti dibagi atas dua bagian di antaranya:

1. Percaya diri (self confidence), yang merupakan keyakinan seseorang akan kemampuan atau kesanggupannya untuk melaksanakan tugas atau pekerjaan.

2. Harga diri (self esteem), merupakan perasaan dan nilai yang dimiliki seseorang tentang bagaimana baiknya orang tersebut menginginkan dirinya.

Dalam teori dan pendapat yang telah diuraikan di atas, maka dapat diambil suatu kesimpulan bahwa konsep diri adalah pandangan dan sikap individu terhadap kemampuan dirinya sendiri, dan konsep diri mempunyai peran penting dalam menentukan dan mengarahkan seluruh tingkah laku individu.

\section{Metodologi Penelitian}

Penelitian ini menggunakan metode survey dengan pendekatan studi korelasional dan metode deskriptif. Pendekatan yang digunakan adalah pendekatan kuantitatif, dimana pendekatan kuantitatif ditandai dengan adanya analisis statistik dengan deskriptif korelasional. Teknik deskriptif digunakan untuk mengungkapkan respon subjek sehingga dapat memberikan gambaran fakta yang sistematis. Teknik korelasional ini digunakan untuk menunjukkan derajat hubungan antara variabel konsep diri dan prestasi belajar matematika siswa di kelas XI SMA Negeri 102 Jakarta Timur, perlakuan terhadap variabel-variabel yang diteliti yaitu konsep diri (X) dan prestasi belajar matematika (Y). Metode ini digunakan untuk mengemukakan ada tidaknya pengaruh antara variabel-variabel konsep diri (X) dengan variabel prestasi belajar Matematika (Y).

Teknik pengumpulan data dilakukan dengan pemberian tes hasil belajar matematika, berupa soal pilihan ganda yang terdiri dari lima pilihan jawaban dengan jumlah soal sebanyak 20 soal. Pengumpulan pemberian kuesioner untuk mengungkap konsep diri siswa, selanjutnya disusun kuesioner sebanyak 30 butir pernyataan melalui skala Likert dengan lima pilihan jawaban. Adapun kompetensi dasar yang diukur sebagai prestasi belajar disesuaikan dengan silabus yang sesuai dengan KTSP.

Instrumen dari masing-masing variabel, terlebih dahulu diujicobakan kepada responden sebanyak 30 orang siswa, yang dipilih dari siswa yang tidak termasuk sebagai sampel penelitian. Dari hasil uji coba tersebut diperoleh kualitas dan kelayakan instrumen yang digunakan dalam penelitian.

\section{Hasil dan Pembahasan}

Data yang diperoleh dalam penelitian ini adalah tentang konsep diri dan prestasi belajar matematika. Dari data yang dikumpulkan selanjutnya disajikan dalam bentuk tabel distribusi frekuensi dan statistik deskriptif berikut: 
Tabel 1. Distribusi Frekuensi Variabel Konsep Diri

\begin{tabular}{cccc}
\hline No & $\begin{array}{c}\text { Kelas } \\
\text { Interval }\end{array}$ & $\boldsymbol{f}_{\boldsymbol{i}}$ & $\boldsymbol{f}_{\text {kum }}$ \\
\hline 1 & $32-40$ & 4 & 4 \\
2 & $41-49$ & 4 & 8 \\
3 & $50-58$ & 11 & 19 \\
4 & $59-67$ & 6 & 25 \\
5 & $68-76$ & 4 & 29 \\
6 & $77-85$ & 1 & 30 \\
\hline$\sum$ & Total & $\mathbf{3 0}$ & \\
\hline
\end{tabular}

Tabel 2. Distribusi Frekuensi Variabel Prestasi Belajar Matematika

\begin{tabular}{cccc}
\hline No & $\begin{array}{c}\text { Kelas } \\
\text { Interval }\end{array}$ & $\boldsymbol{f}_{\boldsymbol{i}}$ & $\boldsymbol{f}$ kum \\
\hline 1 & $7-8$ & 3 & 3 \\
2 & $9-10$ & 7 & 10 \\
3 & $11-12$ & 5 & 15 \\
4 & $13-14$ & 8 & 23 \\
5 & $15-16$ & 6 & 29 \\
6 & $17-18$ & 1 & 30 \\
\hline$\Sigma$ & Total & 30 & \\
\hline
\end{tabular}

Tabel 3. Statistik Deskriptif

\begin{tabular}{ccc}
\hline & Konsep Diri & $\begin{array}{c}\text { Prestasi Belajar } \\
\text { Matematika }\end{array}$ \\
\hline Mean & 56.10 & 12.03 \\
Median & 54.50 & 12.50 \\
Mode & 54 & 9 \\
Std. Deviation & 12.767 & 2.822 \\
\hline & Konsep Diri & Prestasi Belajar \\
& & Matematika \\
\hline Variance & 162.990 & 7.964 \\
Range & 53 & 10 \\
Minimum & 32 & 7 \\
Maximum & 85 & 361 \\
Sum & 1683 &
\end{tabular}

Berdasarkan pada tabel di atas terlihat bahwa data konsep diri mempunyai rentang data sebesar 53, banyaknya kelas 6 , dan panjang kelas 9. Setelah dilakukan distribusi frekuensi diperoleh mean sebesar 55,50; modus sebesar 54,75; median sebesar 55,23; dan standar deviasi sebesar 56,71. Dari nilai-nilai yang diperoleh data responden tergolong tinggi dan cukup beragam. Kemudian data prestasi belajar matematika mempunyai rentang data sebesar 
10, banyaknya kelas 6, dan panjang kelas 2 . Setelah dilakukan distribusi frekuensi diperoleh mean sebesar 12,17; modus sebesar 13,7; median sebesar 12,5; dan standar deviasi sebesar 12,47. Jadi, dapat disimpulkan data konsep diri dan prestasi belajar matematika tergolong cukup baik.

Perhitungan uji normalitas menggunakan uji Liliefors dengan kriteria $\mathrm{L}_{\text {hitung }}<\mathrm{L}_{\text {tabel }}$ berarti data berdistribusi normal. Hasil uji normalitas data konsep diri diperoleh $\mathrm{L}_{0}=0,102$ dan nilai $\mathrm{L}_{\text {tabel }}=0,161$ taraf signifikan 0,05 dengan jumlah responden 30 , karena $\mathrm{L}_{\text {hitung }}$ kurang dari $\mathrm{L}_{\text {tabel }}$ maka data berdistribusi normal. Hasil uji normalitas data prestasi belajar matematika diperoleh $\mathrm{L}_{0}=0,125$ nilai $\mathrm{L}_{\text {tabel }}=0,161$ taraf signifikan 0,05 dengan jumlah responden 30, dari hasil tersebut dapat disimpulkan data berdistribusi normal.

Uji kelinieran regresi dilakukan dengan tabel analisis variasi untuk regresi linier.

Tabel 4. Ringkasan ANOVA Variabel X dan Y Uji Linieritas

\begin{tabular}{lccccc}
\hline Sumber Varians & $\mathbf{d k}$ & $\mathbf{J K}$ & RJK & $\mathbf{F}_{\text {hitung }}$ & $\mathbf{F}_{\text {tabel }}$ \\
\hline Total & 30 & 4575 & - & & \\
Tuna Cocok & 19 & 102,10 & 5,37 & 1,717 & 2,93 \\
Error & 9 & 28,17 & 3,13 & & \\
\hline
\end{tabular}

Mengacu pada Tabel 4. menunjukan bahwa untuk $\alpha=0,05$, dk pembilang $19 \mathrm{dan} \mathrm{dk}$ penyebut 9 didapat harga $F_{\text {tabel }}=2,93$ dan harga $F_{\text {hitung }}=1,717$. Dari data statistik yang diperoleh dapat disimpulkan hubungan antara konsepi siswa dengan prestasi belajar matematika bersifat linier. Dari pengujian hipotesis diperoleh perhitungan sebagai berikut:

Tabel 5. Daftar Analisis Varians Uji Signifikan Koefisien Regresi

\begin{tabular}{lccccc}
\hline $\begin{array}{c}\text { Sumber } \\
\text { Varians }\end{array}$ & Dk & JK & RJK & $\mathbf{F}_{\text {hitung }}$ & $\mathbf{F}_{\text {tabel }}$ \\
\hline Total & 30 & 4575 & - & & \\
Reg (a) & 1 & 4344,03 & 4344,03 & & \\
Reg (b/a) & 1 & 100,7 & 100,7 & & 4,20 \\
Residu & 28 & 130,27 & 4,65 & & \\
\hline
\end{tabular}

Mengacu pada Tabel 5. Hasil uji signifikan koefisien regresi didapat harga $\mathrm{F}_{\text {hitung }}=21,64$ sedangkan harga $F_{\text {tabel }}$ yaitu 4,20 untuk taraf signifikan 0,05 dan $N=30, F_{\text {hitung }}>F_{\text {tabel }}(21,64$ $>$ 4,20) maka $\mathrm{H}_{\mathrm{o}}$ diterima sedangkan $\mathrm{H}_{1}$ ditolak sehingga dapat disimpulkan bahwa terdapat pengaruh signifikan konsep diri siswa terhadap prestasi belajar matematika. Hasil pengujian regresi dari data penelitian ini diperoleh persamaan regresi yaitu $\bar{Y}=3,85+0,146 x$ intercept regresi menyatakan bahwa prestasi belajar matematika siswa sebesar 3,85 tanpa dipengaruhi konsep diri siswa, dan nilai 0,146 menyatakan bahwa setiap kenaikan satuan konsep diri, akan meningkatkan prestasi belajar matematika sebesar 0,146 .

Hubungan antara variabel $\mathrm{X}$, dan variabel $\mathrm{Y}$ diperoleh koefisien korelasi sebesar 0,66. Artinya, terdapat hubungan yang kuat positif antara konsep diri dengan prestasi belajar matematika. Koefisien determinasi didapat nilai sebesar $43,56 \%$ yang menunjukan bahwa konsep diri siswa mempengaruhi hasil belajar matematika sebesar $43,56 \%$ dan sisanya dipengaruhi dari faktor lain. Dari hasil uji hipotesis penelitian yang diperoleh terdapat 
pengaruh signifikan konsep diri siswa terhadap prestasi belajar matematika kelas XI SMA Negeri 102 Jakarta Timur.

Prestasi belajar matematika adalah perubahan tingkah laku siswa yang berkenaan dengan perubahan ranah kognitif siswa yaitu perubahan ke arah pemahaman yang lebih dalam tentang materi dan esensi pelajaran matematika. Perubahan ini berupa pemahaman terhadap konsep-konsep matematika dan kemampuan menggeneralisasi berbagai bentuk pengetahuan setelah memperoleh pengalaman belajar matematika.

Kemampuan kognitif yang diharapkan dari siswa setelah mendapatkan pengalaman belajar meliputi kemampuan dalam membangun pengetahuan tentang matematika, terampil memahami masalah, mengaplikasikan konsep dan pengetahuan yang dimiliki, menganalisa masalah serta mensintesis suatu konsep yang baru dari beberapa konsep yang terpisah-pisah. Terdapat dua faktor yang mempengaruhi prestasi belajar siswa, yaitu faktor dari dalam diri siswa dan dari luar diri siswa. Konsep diri merupakan pandangan siswa berupa kepercayaan akan kelebihan dan kekurangan yang dimiliki diri yang berperan sebagai pendorong untuk melakukan usaha dalam peningkatan prestasi belajar.

Siswa yang memiliki konsep diri tinggi tidak akan cemas menghadapi tantangan dan mampu mengatasi hambatan dalam belajar untuk mencapai kesuksesan. Konsep diri yang tinggi akan mendukung pencapaian prestasi belajar matematika yang tinggi pula. Siswa dengan konsep diri rendah akan memandang lingkungan sekitarnya secara negatif, tidak peduli, gelisah dan tiada keinginan untuk meraih keberhasilan belajar. Konsep diri yang rendah akan menyebabkan prestasi belajar matematika yang rendah pula.

\section{Simpulan dan Saran \\ Simpulan}

Berdasarkan hasil analisis dan pengujian hipotesis di atas menunjukkan bahwa terdapat pengaruh yang positif dan signifikan antara konsep diri terhadap prestasi belajar matematika siswa kelas XI SMA Negeri 102 Jakarta. Dari data kuantitatif yang diperoleh menyatakan semakin tinggi konsep diri siswa maka semakin tinggi pula prestasi belajar matematika siswa.

\section{Saran}

Dari hasil penelitian ini maka saran dan harapan yang bisa peneliti sampaikan yaitu guru dapat lebih meningkatkan kualitas dalam mengajar sebagai upaya meningkatkan prestasi belajar siswa. Banyak hal yang dapat meningkatkan prestasi siswa dalam pembelajaran matematika yang dilakukan di dalam kelas, di antaranya dengan menanamkan rasa percaya diri siswa dalam belajar dan dalam mengahadapi berbagai persoalan. Penanaman kepercayaan diri ini dapat membantu siswa dalam meningkatkan prestasinya dalam belajar. Hal ini dibuktikan dengan hasil penelitian di atas. Oleh karena itu, untuk meningkatkan hasil belajar siswa yang baik, hendaknya guru dapat memberikan rasa percaya diri kepada siswanya. Hendaknya memberikan motivasi kepada siswa untuk dapat meningkatkan prestasinya dalam belajar. Motivasi internal meningkatkan rasa percaya diri siswa dalam menghadapi berbagai persoalan yang dihadapinya, dan motivasi eksternal memberikan penghargaan bagi yang berprestasi dalam pembelajaran di sekolah.

\section{Daftar Pustaka}

Ainon \& Abdullah. (2006). Guru sebagai Pendorong dalam Darjah. Edisi Kemas Kini. Kuala Lumpur: PTS Profesional.

Arikunto, Suharsimi. (2006). Prosedur Penelitian. Jakarta: PT. Rineka Cipta. 
BSNP. (2005). Contoh Pengembangan Kurikulum Tingkat Satuan Pendidikan (KTSP) untuk SMA/MA.

Djiwandono, S. E. W. (2007). Psikologi Pendidikan (rev-2). Jakarta: Grasindo.

Gunawan, A. W. dan Setyiono, A. (2007). Manage Your Mind for Success. Jakarta: Gramedia.

Hakim, Thursan. (2007). Belajar secara Efektif. Jakarta: Niaga Swadaya.

Jalaludin, Rakhmat. (2007). Persepsi dalam Proses Belajar Mengajar. Jakarta: Rajawali Pers.

Kamus Umum Bahasa Indonesia. (2003). Edisi Ketiga. Jakarta: Balai Pustaka.

Russefendi, E. T. (1988). Pengajaran Matematika Modern. Bandung: Tarsito.

Suriasumantri, J. S. (2009). Filsafat Ilmu sebuah Penghantar Populer. Jakarta: Pustaka Sinar Harapan.

Winkel, W. S. (2000). Psikologi Pendidikan dan Evaluasi Belajar. Jakarta: PT. Gramedia. 